\title{
Suicide Terrorism: Perspectives from Muslims in Northern Ghana
}

\author{
Agyemang Frimpong \\ School of Public Service and Governance \\ Ghana Institute of Management and Public Administration \\ P.O. Box AH 50, Achimota-Accra-Ghana \\ E-mail: afrimpong@gimpa.edu.gh
}

Received: May 05, 2016 Accepted: May 27, 2016 Published: June 09, 2016

doi:10.5296/jpag.v6i2.9207 URL: http://dx.doi.org/10.5296/jpag.v6i2.9207

\begin{abstract}
Suicide terrorism has been on the rise in most parts of the world after the terrorist attacks on the United States on September 11, 2001. Ghana as a country is yet to experience any acts of terrorism but recent events in some parts of Northern Nigeria, Kenya, and Somalia and in the Arabian Peninsula have given policymakers a great concern. Some African Muslims with ties to radical Islamic organizations have embraced this phenomenon as a means of settling their grievances. This article attempts to examine the phenomenon of suicide terrorism from the perspectives of Muslims in Northern Ghana. The paper discusses some of the rationale behind the phenomenon and various efforts that have been made to address the psychology behind the phenomenon. It was established that individual psychopathology alone is not the only reason for suicide terrorism but intertwined with other social conditions. In order to develop the appropriate responses and policies to protect the people, there is the need to understand these social conditions. It concludes by discussing the reason why adopting combative approach to the issue has not worked and recommends the use of economic development as well as cultural integration in changing the psychology behind the phenomenon.
\end{abstract}

Keywords: Suicide terrorism, Psychology, Psychopathology, Phenomenon, Lone wolfs 


\section{Introduction}

Most governments across the globe have not been successful trying to understand the psychology behind suicide terrorism (Palmer and Palmer 2004). This has often resulted in the use of conventional methods by the military and intelligence agencies to fight an unconventional war (Johnson 2009). Research exists as to how to fight other forms of terrorism like agro-terrorism and cyber-attacks but not much work has been done in regards to understanding why some African Muslims are beginning to endorse suicide terrorism as a viable method of seeking redress of perceived grievances (Stern 2003). Time and time again, experts in the Western world have failed by way of stereotyping most terrorists by such tags as low education, poverty and hopelessness (Palmer and Palmer 2004). These categorizations have proven to be false, hence the need to have a closer look at Muslims in Africa that have traditionally been viewed as relatively harmless (Stern 2003). In fact Stern (2003) discussed in her work "the ultimate terrorists" that people become suicide terrorists not because of who they are in society but through radicalized and fanatical beliefs.

Although Ghana as a country is yet to experience any acts of terrorism, recent events in neighboring Nigeria and in the horn of Africa has caught the attention of policymakers. The choice of Ghana therefore presents a unique opportunity to find out about the perspectives of Muslims regarding this phenomenon of suicide terrorism. Following the failed attempt of a Nigerian Muslim man to detonate his underwear bomb on board a Northwest Airlines 253 over the airspace of Detroit-USA, several questions have been asked by policymakers, technocrats and ordinary citizens as to whether African Muslims could be the next recruiters for Al Qaeda terrorist organization. The Nigerian Muslim, who later on became known as the "underwear bomber" nearly succeeded in detonating his device which was sewed into his underwear. After being taken into custody, Abdulmutallab told authorities he had been directed by Al-Qaeda, and that he had obtained the device in Yemen (US State Department 2010). Al-Qaeda in the Arabian Peninsula, the organization's affiliate in Yemen, subsequently claimed responsibility for the attack, describing it as revenge for the United States' role in a Yemeni military offensive against al-Qaeda in that country. In explaining the phenomenon of terrorism and suicide terrorism, the research would employ the theoretical frameworks that have been developed by White (2012). This phenomenon was not known to be patronized in Africa but recent events among Muslims in Nigeria, Somalia and the Horn of Africa a compelling need for its curious study among Muslims in Northern Ghana.

\subsection{Islam as a Religion in Ghana}

Islam is based on what Muslims believe are the divine revelations received in seventh century Arabia by the Prophet Muhammad (Pape 2005). The spread of Islam into West Africa, beginning with ancient Ghana in the ninth century, was mainly the result of the commercial activities of North African Muslims. The empires of both Mali and Songhai that followed ancient Ghana in the Western Sudan adopted the religion. Islam made its entry into the northern territories of modern Ghana around the fifteenth century. Mande or Wangara traders and clerics carried the religion into the area (Ghana Muslim Council 2006). The northeastern sector of the country was also influenced by Muslims who escaped the Hausa jihads of 
northern Nigeria in the early nineteenth century.

Most Ghanaian Muslims are Sunni, following the Maliki version of Islamic law. Sufism, involving the organization of mystical brotherhoods (tariq) for the purification and spread of Islam, is not widespread in Ghana. The Tijaniyah and the Qadiriyah brotherhoods, however, are represented. The Ahmadiyah, a Shia sect originating in nineteenth-century India, is the only non-Sunni order in the country (Ghana Muslim Council 2006).

Despite the spread of Islamism in the Middle East, North Africa, and even in Nigeria since the mid-1970s, Ghanaian Muslims and Christians have had excellent relations (Ghana Muslim Council 2006). Guided by the authority of the Ghana Peace Council(GPC), religious and social matters affecting Muslims have often been redressed through negotiations (Ministry of Culture-Ghana 2012). The Muslim Council has also been responsible for arranging pilgrimages to Mecca for believers who can afford the journey. In spite of these achievements, the council has not succeeded in taking initiatives for the upgrading of Islamic schools beyond the provision of basic Quranic instruction. This may explain the economic and technological gap between Muslims and non-Muslims. The Ghanaian Ahmadiyah Movement, which has established a number of vocational training centers, hospitals, and some secondary schools, is an exception.

\section{Theoretical Framework}

The evolution of terrorism could be explained by employing two frameworks espoused by Erving Goffman (1959), namely the meaning framework and structural framework. Meanings are developed by individuals and groups, and different meanings can be attributed to the same event or physical objects because the definitions are always influenced by interpretation. Erving Goffman (1922-1982) was a sociologist who pioneered the use of meaning as a method of analysis and his methodology remains influential in social science. According to Goffman (1959), theories about terrorism in the meaning framework focus on the interpretation individuals and groups give to the actions of others as well as their own actions.

In fact, Mark Juergensmeyer (2003) uses this approach to study the impact of religion on terrorism. He said that violent religious movements and the organizations they create are rooted in the ways certain groups of people view reality. Historians have often used this methodology as well. Bernard Lewis (2002) examined the rise and demise of the Ottoman Turks, the last great Islamic empire, in the face of Western expansion and colonialism. He argued that trouble between Islam and western modernity can be attributed to the meanings each group attributes to historical change. Middle Eastern Muslims tend to search for a lost ideal, whereas the West embraces modernity. If this thesis is applied to the formation of terrorists groups, one would expect to find militant organizations forming within parts of the Islamic world based on the rejection of Western ideals. Other researchers such as Armstrong (2000b, 32-60), Haridakis and Rubin (2005, 39-59); Lewis (2003) have all come up with similar conclusions.

White (2012) also said that we can understand terrorist behavior by looking at the way organizations function. This is what he termed structural framework, meaning social 
constructs are based on systems that provide order. Donald Black (2004) explained the concept of terrorism using this framework. He said that terrorist behavior could be likened to any other human behavior. Black said that groups do not organize and take actions based on the meanings people attribute to the world. Terrorists' organizations usually take action against specific targets because they belong to a structure that exists for a specific purpose. Thus, irrespective of how noble the motives are, the resort to violence qualifies the act as terrorism.

\section{Evolution of Terrorism and Suicide Terrorism}

The meaning of terrorism has changed over the years (US State Department 2010). It is almost impossible to talk about terrorism without discussing the historical context of the terrorist campaign. Modern terrorism originated from the French Revolution (1789-1799) (White 2010). It was a term used to describe the actions of the French government. By 1848, the meaning of the term was employed to describe violent revolutionaries who revolted against governments. Terrorism is arguably the most widely defined concept, registering over 109 definitions (Argo 2004). An overwhelming number of these definitions have been influenced by individual perceptions or by national or regime considerations. Cooper (1976, 1977, 1978 \&2001) first approached the problem by stating that there is a "problem in the problem definition." Therefore terrorism has in his view become a social construct defined by different people within changing social and political realities.

The State Department of the United States of America defines terrorism as premeditated, politically motivated violence perpetrated against non-combatant targets by sub-national groups or clandestine agents, usually intended to influence an audience (United States Department, 2012). Ayatullah Muhammad Ali Taskhiri, considers terrorism as "an act carried out to achieve inhuman and corrupt objective and involving threat to security of any kind and in violation of the rights acknowledged by religion and mankind (Al-Tawhid 1987). This definition highlights the methods rather than motives.

Suicide terrorism on the other hand could be explained as the willingness of individuals to sacrifice their lives to benefit their primary reference group such as a family, military unit, ethnic group or country (White 2012). On the other hand, Robert Pape (2005) suggested that suicide terrorism can be considered as a strategic tool. He said that it is very popular because it works, and although suicide attacks began as a form of religious violence, secular groups use the strategy because it has been effective. Audrey Cronin (2003, 9-11) gives several reasons for the popularity of suicide attacks. They include the generation of high casualties as well as the publicity for the group, ability to control the attacks and the striking of fear into an enemy. Organizations like the Palestinian Liberation Organization (PLO), Tamil-Tigers of Sri Lanka and recently Al Qaeda and Taliban have all used suicide terrorism as a major weapon to advance their cause.

It is also very interesting to note that the use of suicide attacks outside a context of warfare has been traced to the biblical Sampson, and his destruction of the Philistine temple recounted in the book of Judges Chapter 16:26-30. Vs. 30..." and Sampson said, let me die with the Philistines; and he bowed himself with all his might and the house fell upon the lords, 
and upon all the people that were therein. So the dead, which he slew at his death, were more than they which he slew in his life." Biblical Sampson's actions qualify as suicide terrorism not only because it was directed at all who were in the temple, including three thousand men and women but also because of the premeditated intention to die with the Philistines (Rapoport 1984).

It is very difficult to explain the specific reasons why people resort to the use of terrorism. Some of the reasons according to experts are religious obligations, clash of civilizations, overexposure of the public to sensational news, easiness of implementation and humiliation.

Susan Pearce (2005) argues that empirical findings demonstrate that terrorism is partially a religious process. Eli Berman (2009) takes a different approach to religious terrorism. He said that to understand religious terrorism you need to look at the economic factors that cause groups to grow and prosper. He concluded that despite their use of sacred stories and cosmic mythologies, they are hardly religious at all. Berman said that they are neither motivated by rewards in the afterlife nor inspired by the ideals expressed by their religion. Other experts also have a different take on religion and its influence on terrorism.

Crenshaw (2000) and supported by Schweitzer (2005) posited that one of the motivating factors for suicide attacks is the phenomenal emphasis on religious martyrdom. He said that the martyrdom argument particularly dominates in oppressive societies, with youth who feel they do not have several options to make it in life. For such category of people with aborted hopes and dreams, terrorists' organizations may provide a ready conduit to immortality. The value of the martyrdom argument to suicide terrorists is two fold. First, while it holds a high propaganda value (due to media attraction) and therefore makes the case for legitimacy for the group and for the individual attackers, it serves as an avenue to achieving martyrdom and to be remembered by posterity (Cook 2005; Reich and Lacquer 1998, Daniel and Simon, 2005). In essence, the individual and the organization enter into a contract by which the potential attacker agrees to give up his/her life for the purpose of advancing the organization's cause and the organization provides for him an enabling environment to achieve a martyr's identity. Secondly, suicide attacks also provide, in some cases, the perpetrator's family with substantial rewards in the form of honor and financial rewards (Reich and Lacquer 1998).

There seem to have been a growing relationship that has existed between the phenomenon of suicide terrorism and religion(Berman and Laitin, 2004). From the earliest example of biblical Sampson, through the period of the Crusaders and Jihadists, religious factors have provided incentives for extremist followers to adopt suicide attacks. In many of these instances, the attacks have been regarded by religious individuals or groups as a kind of holy war (Berman 2009).

In contemporary times however, the phenomenon has been closely associated with Islam (Emerson 2003; Sageman 2004: Sageman 2008b). An examination of the Holy Quran points to verses that suggest aggression against "unbelievers" (Sageman 2008a). Admittedly though, other verses suggest a religion inclined towards promotion of peace (Sageman 2008a). As expected, militant Muslims and extremist clerics tend to focus only on the first set of verses, 
going the extra step of even taking verses out of context. Verses such as Quran 66:9 " $O$ Prophet, strives hard against the disbelievers and the hypocrites, and be harsh upon them. And their refuge is Hell, and wretched is the destination" to serve the interest of suicide terrorists.

The influence of Islam on terrorism is also seen in the constitutions of some of the most notorious terrorist organizations in the world (Ganor 2000). The official Charter of Hamas, begins with a statement "“....in the name of the most Merciful Allah, the Master of the Universe" and ends with "...the last of our prayers will be praise to Allah, the Master of the Universe." In spite of the spirituality suggested in these statements, the Charter also expresses a commitment to the complete destruction of Israel by stating thus, "Israel will exist and will continue to exist until Islam will obliterate it, just as it obliterated others before it."

Similarly, statements alleged to have come from Osama Bin Laden before his death have laid claim to some Islamic principles and directives. A significant example was in the aftermath of the September 11, attacks against the United States, when he was widely reported to have stated that the attacks were punishments from Allah (US State Department 2002). However, respected Islamic clerics, scholars, politicians and moderate Muslims have continuously reiterated that statements of people such as Bin laden and documents such as the Hamas Charter are merely distortions of the Holy Quran (Wyne 2005). In spite of such attempts to detach Islam from terrorism, the perceived or observable link is rather gaining ground.

Clash of civilizations as used by Huntington (1993; 1996) refers to the cultural conflicts among the world's eight dominant civilizations. He said that civilizations are defined by common moral values, behaviors, social structures, and economic systems and religion plays an important role in defining civilization. Huntington argued that there are eight primary cultural paradigms or civilizations dominating the modern world which include Western, Confucian, Japanese, Islamic, Hindu, Slavic-Orthodox, Latin American and African. He said that Western civilization of which Christianity is part of has been confronting Islam. However, some experts disagree with his assessment. John Esposito (1999, 238-242) disagreed with Huntington's assessment on two levels. He said that culture or civilization is defined by more than religion. Rather a mixture of history, language, geography, social structure and ethnic factors all influence civilization. He also disagreed with Huntington's assessment that Western Christianity has been confronting Islamic civilization. Esposito argued that there is no Islamic civilization and that the world of Islam is politically and socially diverse and so not a single civilization. Similarly, Daniel Pipes (2003, 248-251) disagreed with the majority of Huntington's assertion. Pipes said that the major clash is not between civilizations rather it is within Islamic civilization. He goes on to say that moderate Muslims are attempting to engage modernity, and they are forced to fight violent fanatics who are trying to re-interpret the religion.

Cooper (1979) argued that one of the reasons for terrorism is overexposure of people to sensational news. Cooper believes that the public has become overly exposed to news about terrorism. This he believed encourages the potential terrorists to think of the next big 
extraordinary thing to capture the attention of the news media.

Suicide terrorism is less complicated and compromising than other forms of terrorism(Atram, 2004).They are less complicated because they only require basic supplies such as pipes, batteries, wires, bolts and fertilizer rather than sophisticated or high-tech materials (Pipes 2003). They are less compromising because there is no chance that the terrorist can surrender any information under interrogation because his/her death is certain (Pipes 2003).

\subsection{Humiliation}

When people feel humiliated, they can do anything they think could restore their pride. Humiliation is different from fear. Humiliation is an emotional process that seeks to discipline the humiliated party's behavior by attacking and lowering their own and others' perceptions of whether they deserve respect(Krueger and Maleckvo, 2005). According to Riaz Hassan (2009), in Abu Ghraib prison the techniques - forced nudity, simulated sex with another man in front of a female, made to bark like a dog and being photographed doing that - were not intended to inflict physical pain but to create total submission and obedience. He continued by saying that these practices did not humiliate the prisoners alone but was felt and seen as humiliating by all Iraqis. Hassan (2009) concluded that it was evident in the reactions that followed the publication of the prisoner abuse photographs. In the months following their release daily suicide bombing attacks in Iraq increased dramatically. Riaz Hassan (2009) also said that "counterinsurgency operations in countries like Iraq, the Palestinian territories, Sri Lanka, Pakistan and Afghanistan involving random house searches, interrogations, arrests and other violations of human dignity are followed by an increase in suicide attacks."'(243)

\section{Description of the Study Area}

In order to put this study into the right context, it is very important to understand the geography and demographic characteristics of the area. The Northern Region, which occupies an area of about 70,383 square kilometers, is the largest region in Ghana in terms of land area (Ghana Statistical Service 2011). It shares boundaries with the Upper East and the Upper West Regions to the north, the Brong Ahafo and the Volta Regions to the south, and two neighboring countries, the Republic of Togo to the east, and Cote d' Ivoire to the west. According to the Ghana Statistical Service data, more than half of the populations of the region (56.2 percent) are Muslims. The rest are largely adherents of Traditional religion (21.3 percent), Christians (19.3 percent) and other religious groups (3.3 percent).

There is a wide gap in educational attainment between the country as a whole and the region. At the national level, 38.0 percent of the population, 6 years and older, have no formal educational training compared with 72.3 percent (66.6 percent males and 77.9 percent females) in the Upper West Region. The district with the lowest percentage of the population with no formal educational training is Tamale with 50.8 percent (42.5 percent males and 59.0 percent females). On the other hand, Gushiegu-Karaga has the highest proportion (84.3 percent) of the population with no formal educational training (79.3 percent males and 89.0 percent females) (Ghana Statistical Service 2011).

The high proportion of the population of the region, with no formal educational training, 
ranging from 42.5 percent to 79.3 percent for males and 59.0 percent to 89.0 percent for females, should be of great concern for the regional administration in particular. The bulk (71.2 percent) of the economically active population in the region is employed in Agriculture. Only 5.7 percent of the workforce is made up of Professionals, Administrative or Clerical staff. The rest (23.1 percent) are in Sales, Services, and Transport and Production. Among the districts, Zabzugu-Tatale has the highest proportion in Agriculture (87.7 percent) (Ghana Statiscal Service, 2011).

\subsection{Data and Method}

In order to fully explore the phenomenon of suicide terrorism among Moslems, this study designed survey instruments for four (4) Muslim communities in Northern Ghana. The choice of the Northern Region in Ghana was based on the population density of Muslims population (56.2 percent) which is deemed to be very high. In all, a 25-item self-reporting survey was administered to 500 participants in the four Muslim communities. Survey Questionnaires which covered areas such as demographics, government response to terrorism and views of Moslems towards suicide terrorism were administered over a period of four (4) Fridays. With the help of two assistants who are natives from the area, the study used the snowball approach to identify participants after the four communities have been selected. Questionnaires were handed over to people with formal education who could read and collected later in the day. Participants who could not read had to be assisted by the research assistants, who read the questions to them and recorded their responses immediately. Simple descriptive statistics was adopted to look out for trends within the data.

\subsection{Discussion of Survey Results}

The study successfully administered 475 survey instruments to willing participants, putting the rate of response at 95 percent. From the 475 responses, 305 were males and 170 were females. Participants were put into age categories as follows: (25 percent) for ages $18-25 ; 45$ percent (26-36 years); 18 percent (37-50years) and 125 (over 50 years). The level of education were somewhat spread with 25 percent being educated in Muslim schools; 24 percent had primary education; 20 percent had Senior High School education; 12 percent with College degrees and 19 percent with no formal education. Income levels were very difficult to determine because people were just not willing to disclose how much money they were earning.

On the question of whether respondents were likely to undertake a "jihad" if presented with an opportunity, 175 participants representing 36.8 percent answered "Yes" while 300 participants representing 63.1 percent answered "No." This was quite surprising because from the Western world, people think that an overwhelming majority of Moslems would be ready to do "jihad" if presented with the opportunity. Although majority of the respondents responded in the negative, the number of those ready to undertake "jihad" should be worrying for policymakers. When asked whether they believed Western governments are anti-Moslems, 29 percent of the respondents said "yes" while 71 percent said "no." Participants were also asked whether they believe suicide terrorism was the best option to get grievances redressed and only 15.2 percent answered "yes" while 84.8 percent said they not think that was the best 
option. The study also wanted to know from participants whether current government measures in fighting terrorism were enough to deter would-be terrorists and about 69.3 percent said "yes" while 30.7 percent said "no" as there are still loopholes in security.

Religious violence has been spreading across certain Muslim communities in Northern Nigeria and most of the times it is because of religious intolerance by the various religions. The study asked participants whether there was religious tolerance in Ghana and 96.4 percent said "Yes" while only 3.6 percent answered as "No". The reason that was given for this overwhelming response was that Christians and Moslems in Ghana have co-existed peacefully for years and that all religions respect each other. Another reason given was the fact that most schools in the Northern region are Missionary-based schools and that Moslems learn from childhood that it is possible to live side by side with people who are not of the same faith.

The study also wanted to know from participants whether they were devout Moslems (observes most of the 5 pillars of Islam) and 92.4 percent said "Yes" while 7.6 percent said "no". This was very significant piece of the research because the study wanted to find out how committed participants were to the Islamic religion. It could therefore be concluded that survey participants were devout Moslems who followed the teachings in the Quran. Radical Islam has been on the rise and one of the ways by which it is gaining ground is through the use of the internet. People in the West especially are being radicalized by extremist clerics and Moslems who have been putting jihadist materials on the internet. The research therefore wanted to find out whether participants have access to the internet. Out of the 475 participants, 295 (representing 62.1 percent) had access to the internet while 180 (representing 37.9 percent) did not have access. This was very significant because internet is the easiest method of radicalization and recruitment by jihadist groups. There is therefore the need for policy makers to keep an eye over what is being transmitted over the internet in these internet cafes. It was also observed that out of the $62.1 \%$ who access to the internet, $51 \%$ had had to travel some distance in order to get to internet cafes while only $10 \%$ had it in their homes.

When asked about how participants get informed about events happening around the world: 64 percent of participants said through radio; 23 percent through TV; 4 percent through local newspapers and about $10 \%$ through the internet. It is however significant that even though a small percentage of participants had access to the internet, they can still get access to some of the radical internet postings. This is a worrying situation and that calls for serious attention from policymakers. It is also very worrying to have about 37 percent of the respondents willing to undertake jihad when presented with an opportunity. This is a ticking bomb ready to explode. Such people could easily be targeted by radical jihadist groups who may influence them with propaganda materials on the internet and also the promise of better after life.

It also became very clear from the survey results that Muslims in Ghana do not feel alienated in any way by government policies. In fact 90 percent of the respondents said that government policies have not been biased towards any particular religion. Some of them were 
of the opinion that in the sub-region, Ghana happens to be one of the few countries that guarantees Muslim holidays as National Holidays. This, they said, makes them feel proud to be Ghanaian Muslims. Muslims have two National Holidays in Ghana namely Eid Fitir and Eid Adar. Since democratic government rule took root in 1992, Muslims in Ghana have been used by politicians and their parties for electoral advantages. Therefore, any policy deemed biased towards Islam and its followers could spell doom for the incumbent government that implemented that particular policy. Due to this reason, government policies towards Muslims in Ghana have been very favorable. It is also worthy to note that although Muslims are highly concentrated in three regions of Ghana (Northern, Upper East and Upper West), there are Muslim communities scattered across the length and breadth of the country. There has also been a trend where the various political parties choose a Muslim or someone from the three regions in the North as their Vice President. This allows a native of those three regions to have influence over policies and laws that affect them.

\section{Future Research Studies}

The preconceived ideas that military action can suppress suicide terrorism, that suicide terrorist are mentally deranged, and that they are poor can all be called into question. There is even evidence that they are not entirely opposed to "Western Freedoms," favoring at least democratic elections to grab power (Pipe 2003). These are issues that invite further study. Another area of interest could be to explore the recruitment of prospective terrorists, to determine which of these people have been recruited by outside groups to undertake jihad activities in the West and which are "home grown."

\section{Conclusion}

Suicide terrorism is a threat to all humanity. Minimizing this threat calls for a holistic understanding of the methods as well as the environment that encourages their growth. It involves the battle of ideologies and beliefs and defies conventional war tactics. In developing countries like Ghana, there is the need for policy makers to watch out for propaganda materials on the internet and infiltrate intelligence officials into hot spot areas. There is the need to adopt a mixed approach that utilizes both military and non-military approaches. Policymakers have to influence cultures with values and policies that promote love, equality of economic opportunities and respect for other people irrespective of race, color, creed and religion.

Another area of fighting suicide terrorists is countering the morale damage of these attacks. As already indicated, suicide terrorists also aim at winning a psychological war by lowering public morale. Any attempt at managing the threat of suicide terrorism must also include measures that aim at strengthening the capacity of building the resiliency of the public in dealing with the psychological impact of suicide attacks. There is no need to demonize terrorists but rather policymakers should implement policies that are all inclusive from civil society, religious institutions, schools, workplaces and the media. The slogan should be to try and influence people at young age before they get radicalized and the media has a big role to play in this effort. 


\section{References}

Armstrong, Karen. 2000. The battle for God. New York: Random House. The Army of God Manual. www.armyofgod.comGod.com/AOGhistory. [Accessed October 15, 2011]

Argo, Nichole. 2004. Understanding and defusing human bombers: The Palestinian case and pursuit of martyrdom complex. A Paper Presented at the International Studies Association. Montreal, Quebec. March 2004.

Atran, Scott. 2004. Mishandling suicide terrorism. Washington Quarterly 27 (3): 67-90.

Ayatullah Shaykh Muhammed “Al Taskhiri”. 1987. Towards a definition of Terrorism, AlTawhid, Vol.1 available at http://www.al-islam.org/al-tawhid/def-terrorism.htm accessed on 02/05/2014.

Berman, Eli and David Laitin. 2004. Rational martyrs vs hand targets: Evidence on the tactical use of suicide attacks. In Suicide bombing from an Interdisciplinary Perspective, eds.Meyersson Milgrom. New Jersey: Princeton University Press.

Berman, Eli. 2009. Radical, religious and violent: The new economics of terrorism. Boston: MIT Press.

Black, Donald. 2004. The Geometry of Terrorism. Sociological Theory 22(1): 14-25

Colum, Lynch. 2003. Volunteers swell a reviving Qaeda: UN warns In International Herald Tribune. Medical Quarterly 1: 8-18.

Cooper, Harry. 1976. The Terrorist and the Victim. Victimology, 1, No.2: 229-239

Cooper, Harry. 1977. What is terrorism? A psychological perspective. Legal Medical Quarterly, 1:8-18.

Cooper, Harry. 1978. Terrorism: The problem of problem definition. Chitty's Law Journal, 26:105-108.

Cooper, Harry. 2001. Terrorism: The problem of definition revisited. American Behavioral Scientist, 44: 881-893.

Cook, David. 2005. Understanding Jihad (First Edition).University of California Press.

Crenshaw, Martha. 2000. Terrorism in comparative perspective. In Countering Suicide Terrorism. Herzliya: International Policy Institute for Counter Terrorism.

Cronin, Audrey. 2003. Al-Qaeda after the Iraq conflict. Congressional Reference Service. www.fas.org/irp/crs/RS21529.pdf [Accessed July 10, 2012]

Daniel, Benjamin and Steven Simon. 2005. The next attack: The failure of the War on Terror and strategy for getting it right. New Yok, NY: Times Books. 


\section{Macrothink}

Journal of Public Administration and Governance ISSN 2161-7104 2016, Vol. 6, No. 2

Emerson, Steven. 2003. American Jihad: The terrorists living among us. Free Press

Esposito, John. 1999. The Islamic Threat: Myth or reality. New York: Oxford University Press.

Ganor, Boaz. 2000. Suicide attacks in Israel. In Countering Suicide Terrorism. Herzliya: International Policy Institute for Counter Terrorism.

Ghana Muslim Council(2006). Report on Religious Diversity.

Ghana Statistical Service. 2011. Regional Reports. http://www.statsghana.gov.gh/

Goffman, Erving. 1959. The presentation of self in everyday life. Garden City, NY: Doubleday.

Hassan, Riaz. 2004. Terrorist and Their Tools Part 1. http://yale.edu/display.yaleglobal.article. [Accessed November 15, 2011].

Hassan, Riaz. 2009. Life as a weapon: The global rise of suicide bombings. Melbourne University Press.

Huntington, Samuel. 1993. The clash of civilizations. Foreign Affairs, 72: 22-49.

Huntington, Samuel. 1996. The clash of civilizations and the remaking of the world order. New York: Simon and Schuster.

Johnson, Thomas. 2009. The war on terrorism: A collision of values, strategies and societies. CRC Press.

Krueger, Alan and Jitka Maleckvo. 2005. Seeking the roots of terror.

http://chronicle.com/free/vv9/139/39601001.htm. [Accessed on October 20, 2014]

Lewis, Bernard. 2002. What went wrong? The clash between Islam and modernity in the Middle East. New York: Oxford University Press.

Lewis, Bernard. 2003. The Crisis in Islam: Holy War and Unholy Terror. New York: Random House.

Ministry of Culture, Tourism and Creative Arts, Ghana. 2012.

Palmer, Monte and Princess Palmer. 2004. At the heart of terror: Islam, Jihadists and America's War on Terrorism. Lindham, MD: Rowman and Littlefield.

Pape, Robert. 2005. Dying to win: The strategic logic of suicide terrorism. New York: Random House.

Paul M. Haridakis and Alan M. Rubin. 2005. Third Person Effects in the aftermath of Terrorism, Mass Communication and Society, 8:1, 39-59.

Pearce, Susana. 2005. Religious rage: A quantitative analysis of the intensity of religious conflicts. Terrorism and Political Violence, 17(3): 333-352. 
Pipes, Daniel. 2003. Militant Islam reaches America. New York: Norton

Rapoport, David C. 1984. Fear and trembling: Terrorism in three religious traditions. American Political Science Review, 78(3): 658-677.

Reich, Walter and Walter Lacquer. 1998. Origins of terrorism: Psychologies, ideologies, theologies and states of mind. Woodrow Wilson Center Press.

Sageman, Marc. 2004. Understanding terror networks. Philadelphia: University of Pennsylvania Press.

Sageman, Marc. 2008a. Leaderless Jihad: Terror networks in the twenty-first century. University of Pennsylvania Press.

Sageman, Marc. 2008b. The reality of grass root terrorism. Foreign Affairs, 87(4): 163-166

Schweitzer, Yoram. 2004. Suicide Terrorism: Historical Background.

www.pbs.org/wnet/wideangle/shows/suicide/index.html. [Accessed on October 10, 2011].

Stern, Jessica. 2003. Terror in the Nature of God: Why Religious Militants Kill. Harper Collins: New York.

US State Department. 2002. Country Reports on Terrorism. Bureau of Conter-Terrorism, Available at www.state.gov .

US State Department. 2010. Country Reports on Terrorism. Bureau of Conter-Terrorism, Available at www.state.gov

US State Department. 2012. Country Reports on Terrorism. Bureau of Conter-Terrorism, Available at www.state.gov

White, John. 2012. Terrorism and homeland security. Wadsworth Cengage Learning.

Wyne, Ali. 2005. Suicide terrorism as a strategy: Case study of Hamas and the Kurdistan workers party. Strategic Insights, 4 (7): 2-7.

\section{Copyright Disclaimer}

Copyright for this article is retained by the author(s), with first publication rights granted to the journal.

This is an open-access article distributed under the terms and conditions of the Creative Commons Attribution license (http://creativecommons.org/licenses/by/3.0/). 